\title{
Inflation \& Economic Freedom: Evidence from MENA Region
}

\author{
*Ahmad Jafari Samimi, Mahmood Mahmoodzadeh, Leila Shadabi \\ Islamic Azad University, Firuzkuh Branch, Firuzkuh, Iran \\ *jafarisa@yahoo.com
}

\begin{abstract}
Since1980s economic freedom policies have been popular in most countries, especially in developing countries. There are many studies regarding relationship between economic freedom and other socio-economic variables, but few dealt directly with the impact of economic freedom on inflation. This study analyses the effect of economic freedom on inflation in MENA region during 1996- 2006 using panel data regression analysis on the basis of the so- called Gordon theory. Our findings indicate that although the impact of economic freedom on inflationis not considerable butit is statistically significance.
\end{abstract}

\section{Key Words: Inflation, Economic Freedom, MENA Region}

\section{Introduction}

The economic freedom is a state in which there is no imposition for ranking the requirements and allocating the production equipment to economic units. People have economic freedom if their possessions are gained without force, aggression and it is safe from others physical aggression and they are free in exchanging their possessions until they don't violate others property rights (Gwartney and Lawson, 2003). It is widely believed that it has a lot of benefits and can provide suitable methods for economic state men's decision making in different countries. So, it is very notable for the economists to measure the economic freedom of a country. After the numerous studies (which were administered by economists) two indexes were defined for economic freedom degree by Fraser Institute and Heritage Foundation. Although these indexes are different in the range of the extreme number and counting methods, but they include similar field. The index of Fraser institute is a weight mean of five calculated areas out of twenty- one sub-indexes and has a range between zero and tenwhenever the extreme number is closer to ten, it's a symptom of higher freedom and whenever it's closer to zero, it's vice versa.The index of Heritage foundation is a result of a simple mean of ten calculated sub-indexes out of thirty four indexes and has a range between zero and one hundred, the raise of extreme number shows that the country is freer. According to De-Haan's calculating fields (De-Haan and Strum, 2000) international trading, international flow investment, black market, taxation, the rate of government's intervention in economy, financial policies and inflation, rules of banking, price controlling policies, and market equilibrium and the property rights are included in both indexes. In spite of similar fields, the difference in counting methods led to choice Heritage foundation index for this study. It is better because all of sub-indexes of it are important like together. Heritage's sub index areas include: trading freedom, business freedom, financial freedom, government's intervention in economy, monetary freedom, investment freedom, fiscal freedom, property rights, freedom from corruption and labor freedom.

The theories of economics suggest that increase in economic freedom will lead to growth in GDP and employment (De Haan \& Strum, 2000; Carlsson \& Lundstrom 2002; Stroup, 2007). Considering the positive effect of economic freedom on growth, we expect a negative effect on prices. But the experience of applying policies to achieve higher degrees of economic freedom in some countries -such as Iran in 1990 's- was accompanied with higher inflation.The purpose of this study is to examine the effects of economic freedom on inflation rate. The paper question is whether freer degrees in economy have a significant effect on inflation or these changes occur by chance without any statistically significant economic effect? To answer this question, we use the panel data of 17 countries (MENA region) using of Gordon theory during 1996 - 2006.These countries belong to developing countries and most of themare exporting natural resources and are geographically located beside each other. In this region $6 \%$ of the world populationis living and there is $45 \%$ of world gas oil and $60 \%$ of world oil. Some of them have liberalization policies. The period of study is from 1996 to 2006 and the statistical data from these countries have been obtained from (World Bank, 2008) and (Heritage, 2009). Djibouti, Iraq, Lebanon and United Arab Emirates have been removed from the area (21 countries) because of statistical data deficiencies. 
The remainder of this paper is structured as follows: Section 2 provides literature review.In this case we offer some recent investigations that they are aboutthe effect of economic freedom's sub-index on inflation. Section 3 outlines the data and the econometric methodology. Section 4 presents our finding. Finally, Section 5 summarizes our findings and concludes the paper.

\section{Literature Review}

It is not predictable to answer this question that whetherthe impact of economic freedom on inflation is positive or negative. Trading freedom, financial freedom, property rights and government size in economy are sub-indexes whose effects on inflation were examined in previous studies. There is no exact judgment about the effect of the government's intervention in economy. Barro (1990) believes that the governments generating costs are important in growth. According to this analysis, it may have negative effects on inflation. On the other hand, a raise in the governments consumed costs will increase inflation. So what effects the governments total intervention has on inflation is a subject which can be studied as a case study. Financial freedom with the symbol of the Central Bank Independence was examined by Banaian and Luksetich (2001) and Siklos (2008). Banaian and Luksetich (2001) concluded that the Central BankIndependence leads in a lower inflation and Siklos (2008) showed that increasing all the significant factors in the Central Bank Independence calculating do not help to reduce the inflation rate and there is no fixed definition of the central bank's independence in all countries. In fact, the central bank's independences increase the desire for price stability.

Romer (1993), Lane (1997), Gruben and MClead (2004), Alfaro (2005), Daniels and VanHoose (2006), Jin (2006) and Badinger (2009) examined relationship between openness and inflation and they came up different results. Romer (1993) presented an investigation about this subject that based on this research the effect of trade freedom on inflation is negative. This subject was examined again by Terra in 1998. Terra showed that the negative relationship between inflation and freedom is not robust. Her investigation shows in 1990's this relationship has occurred in countries with debt crisis. Lane (1997) showed there was an inverse relationship between openness and inflation. This relation is strengthened when country size is held consistent, so he suggested trade openness should be taken seriously as a determinant of average inflation in the long-run. Gruben and MClead (2004) approved the results of Terra (1998) in their research and have showed that trade freedom in 90's has had a stronger anti-inflationary effect on economies with floating exchange rate system. Alfaro (2005) examined Romer's subject (Romer, 1993) since 1973 - 1998 in a panel data model. His findings show that trade that is more open has not had a restrictive role on inflation in the short time. Daniels and VanHoose (2006) showed inverse relationship between openness and inflation was not necessarily the case. Jin (2006) showed a shock to openness has negative effects on the price level but no longer-run effects. The negative price effect of openness was also consistent which the general belief that increasing openness reduces tariffs, so to have lower import prices, in South Korea, before the crises of 1997-1998. Badinger contemplated relationship between inflation and openness and financial freedom and size of the countries (Badinger, 2009). He showed that openness and financial freedom have a negative and measurable effect on inflation and his results is approaching to Lane's results when he considers the population and the state of countries, but this relationship is not robust for the OECD countries.

Barro and Lee (2005) investigated the effect of IMF loan programs on economic growth and other variables. They have shown that the fulfillment of the condition of IMF and World Bank loan did not have significant effects on inflation. Carare and Stone (2006) in their computation inflation targeting, observed that property right's coefficient is positive and significant in 41 countries. Barlow (2010) assessed the effect of structural reforms in inflationreducing in 25of transitioneconomics. His investigation showed that trade liberalization and the reform of credit allocationcan reduce inflation. It will be especially important for bringing inflation below $10 \%$. In addition, if the countries have privatization planning, their inflation will be raised. Sufian \& Habibullah (2010) investigated the relationship between the economic freedom and efficiency of banks from 1999 to 2007. They showed thatmonetary freedom led to less inflation at $1 \%$ confidence in Malaysia. The efficiency of banks increases with the economic freedom and therefore appropriate credit allocation due to the presence of more efficient enterprises leads to less inflation.The empirical studies have not identical results and the impact of economic freedom on the inflation depends on economic situation. So, in this paper, we investigate the effect of economic freedom on inflation in MENA region. All countries of MENA are in developing countries group and liberalization is performed in the area. The methodology of research is offered below. 


\section{Methodology \& Statistical Evidence}

According to the information obtained from IMF web-site about inflation of the countries in the region and information obtained from Heritage web-site about their economic freedom, in this region economic freedom had a constant mean with Heritage index. This was between 57 and 60 from 1996 to 2006, but these countries did not have a steady trend.Their indexes were sometimes downward and sometimes upward. Bahrain has had the largest mean (74.07), and Libya has had the smallest mean index (35.25) of economic freedom. The largest index was in Bahrain in 2003, the index was 76.3 and the smallest in Libya in 1996 with 31.7. The mean of inflation rose from 4.5 in 2000 to 11.5 in 2006 and fell to 6.9 in 2007 in region. In these years, Turkey with 27.43has the largest and Libya with 0.48 has the smallest mean of inflation.By comparing inflation graph with economic freedom graph, (Figure 1) the inflation reduced with increase in economic freedom in 1998 and vice versa in 1999. These variables were without a big change in other years. But in the last year in the study period an inflation increase can be seen with increase in economic freedom. So, we can't find a robust relationship in the graphs.

\section{Figure (1): Inflation averages and economic freedom averages in the region}
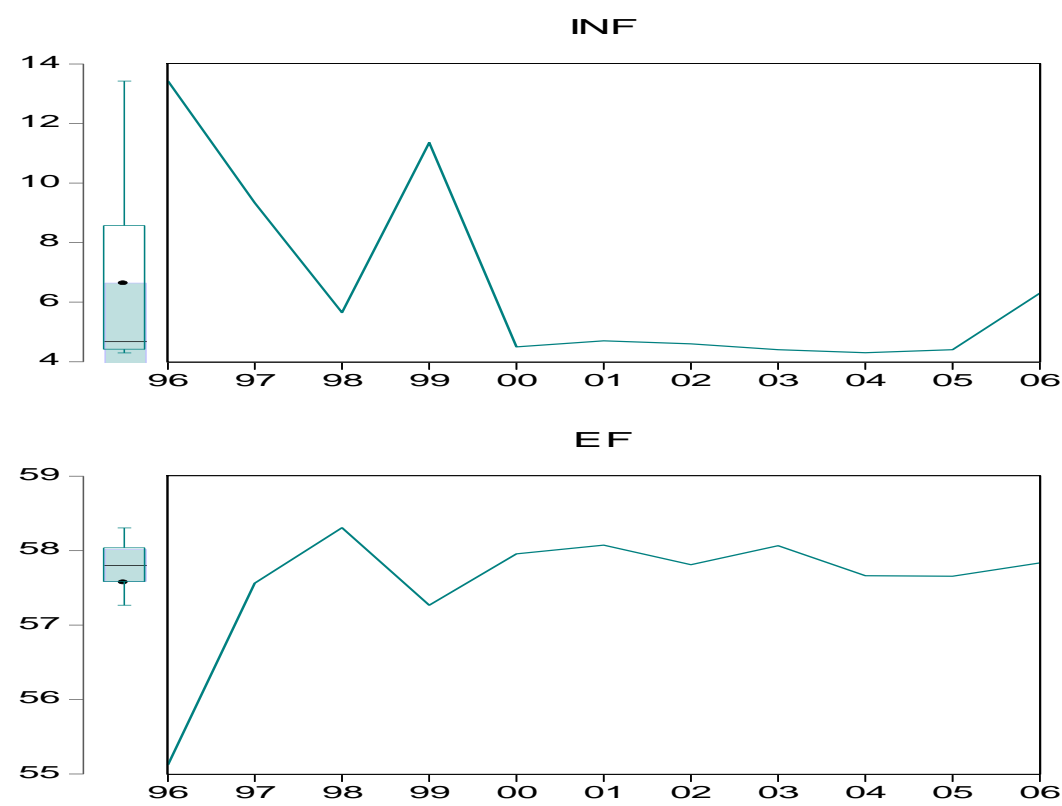

Source: IMF web-site \& Heritage web-site

If the countries in the region are divided into four groups according to Heritage definition, and the groups are comparedfor their inflation averages,the results are as in Table 1.The relationship between economic freedom and qualified description and abundance of countries in every level have been shown in table1

Table1: Economic freedom and Inflation data in MENA region

\begin{tabular}{lllll}
\hline Number & Countries & Situation & Quantity & $\begin{array}{l}\text { Mean } \\
\text { Inflation }\end{array}$ \\
\hline 0 & & free & $80-100$ & \\
2 & Bahrain, Cyprus & Mostly free & $70-79.9$ & 4 \\
6 & $\begin{array}{l}\text { Qatar, Saudi Arabia, Israel, Oman, Jordan, } \\
\text { Kuwait, Almost free }\end{array}$ & $60-60.9$ & 5 \\
& $\begin{array}{l}\text { Yemen, Egypt, Algeria, Turkey, Morocco, } \\
6\end{array}$ & $\begin{array}{l}\text { Mostly } \\
\text { closed } \\
\text { Tunisia }\end{array}$ & $50-59.9$ & 9 \\
closed & $0-49.9$ & 7 \\
\hline
\end{tabular}

Source: Heritage foundation and processed by authors

Consideration about economic freedom and inflation in the region shows groups of "closed", "almost free" and "mostly free" have had lower than groups of "mostly closed". It seems that economic freedom raises 
inflation rate at first but after achieving a certain point it willreduce inflation rate.Figure 1 shows average of inflation in every group. The group of mostly closed has the highest inflation rate.

\section{Figure (2): Relationship between inflation and economic freedom}

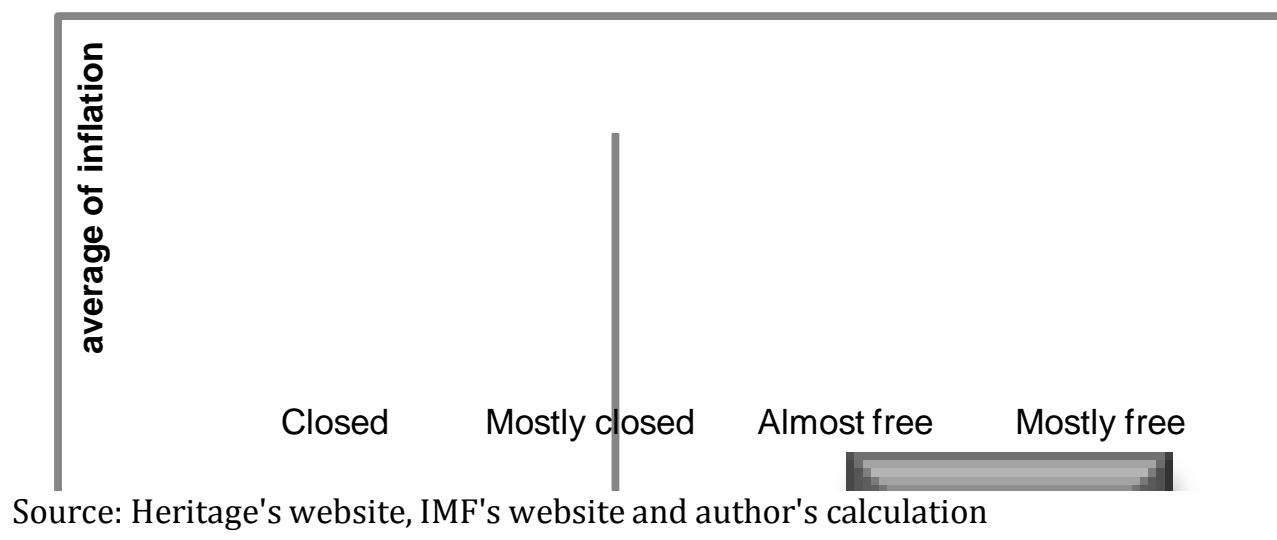

Our model, is based on Gordon balanced inflation theory.In this theory he stated the inflation roots in 3 groups; total demand, total supply and inflation inertia. Using statistical data according to this theory, an index is considered from each of these factors. For entering the first factor, changing in total demand out of cash growth has been used.This index can be a good symbol of demand increase (which is shown by $(M)$. For the second factor, changing in total supply, real GDP growth is arranged. But there is another factor known as inflation inertia, which the previous period of inflation $\left(\inf _{(-1)}\right)$ is considered a suitable symbol for it.In the last stage, economic freedom index (EF), which is on objective variable, is added, then its coefficient is verified and its effect on inflation will be analyzed. So, we will have a balanced equation of inflation which is used for studying the economic freedom's effect on inflation.

$\ln f_{\text {it }}=\alpha_{*}+\alpha_{1} M_{\text {it }}^{\circ}+\alpha_{2} y_{i t}^{\circ}+\alpha_{1} \ln f_{\text {it }}+\alpha_{4} E F_{\text {it }}+e_{\text {it }}$

Where inf is inflation, $\mathrm{M}$ is liquidity stock, $\mathrm{y}$ is real gross domestic production, $\inf _{(-1)}$ is inflation in the last year, $\mathrm{EF}$ is economic freedom, i denotes cross-sections and t denotes time and dot on the variable denote their growth.In order to estimate the above model we have used the logarithmic version as seen below.

$\log C p i_{\text {it }}=a+\beta_{1} \log M_{\text {it }}+\beta_{2} \log Y_{\text {it }}+\beta_{1} \log C$ pitit -1$\}+\beta_{4} E F_{\text {it }}+e_{\text {it }}$

CPI is consumer price index, $\mathrm{M}$ is cash volume, $\mathrm{Y}$ is real gross domestic product and $\mathrm{CPI}(-1)$ is consumer price index in the last year. [Log] in the beginning of variable is natural logarithm (For data sources see World Bank, 2008 \& The Heritage foundation,2009). In this function, i denotes cross-sections and $t$ denotes time. In this study panel data has been used and Likelihood Ratio test and Husman test show that fixed effect panel data is correct. In fourth part of paper our finding will be offered.

\section{Finding and Concluding Remarks}

Before doing regression, it is important that $\mathrm{F}$ Limer test and Husman test are done. The results showed the fixed effect is the best and they show in table 2. At first, we estimated the model about all countries in the region. The result showed economic freedom increased inflation, but the coefficient is negligible. In the second stages, in order to remove the anisotropy of the countries, based on economic freedom and inflation, other estimations were performed by separating the countries. At first, the area is divided in two groups; "nearly free" and "nearly closed", and this model has been estimated for each group. The summary of the model's coefficient estimation results are shown in the table2. T statistics are shown below of coefficient in parenthesis. 
Table 2: The Regression Results in Sample and sub-groups

\begin{tabular}{lrrr}
\hline Independent variable & All countries in region & Nearly closed & Nearly free \\
\hline Intercept & -1.5 & -2.53 & -2.27 \\
& $(-3.21)$ & $(2.37)$ & $(-4.22)$ \\
$\log \left(\mathrm{M}_{\mathrm{ij}}\right)$ & 0.04 & 0.05 & 0.003 \\
& $(2.61)$ & $(1.91)$ & $0.2)$ \\
$\log \left(\mathrm{Y}_{\mathrm{ij}}\right)$ & 0.05 & 0.08 & 0.13 \\
& $(1.7)$ & $(1.32)$ & $(3.6)$ \\
$\log \left(\mathrm{cpi}_{\mathrm{ij}(-1)}\right)$ & 0.83 & 0.80 & 0.75 \\
& $(49.8)$ & $(30.7)$ & $(18.69)$ \\
$\mathrm{EF}_{\mathrm{ij}}$ & 0.002 & 0.003 & 0.002 \\
$\mathrm{R}^{2}$ & $(4.63)$ & $(3.78)$ & $(3.57)$ \\
$\mathrm{F}$ test & 0.98 & 0.98 & 0.97 \\
Husman test & 17.95 & 18.11 & 12.37 \\
Model & 15.58 & 19.25 & 41.62 \\
& Fixed effect panel data & Fixed effect panel data & Fixed effect panel \\
\hline
\end{tabular}

All estimated coefficients except GDP growth are statistically significant and support the theory. In addition, the average growth of GDP in these countries was between 3 to 5 which is not a considerable growth (Another estimation without $\log (\mathrm{Y})$ didn't change the result). The change in liquidity stock has a significant effect on inflation. The inflation inertia has the biggest effect on inflation and it is exactly acceptable because of economies structure in the region countries.The economic freedom coefficient (which is the objective variable) is positive which it means that there is a positive relationship between economic freedom and inflation rate. The important point is that this coefficient has a small value with significant statistic $t$ student. It means that in these countries in the studied period, although we are sure about the presence of this effect, but there is no considerable effect leading from economic freedom changes on inflation rate. In other words, by a graduated increase in economic freedom, the inflation will increase as much as $0.002 \%$.The results show that the effect of economic freedom on inflation is $0.003 \%$ in "almost closed" countries and it is more than "almost free" countries. Therefore, the results are similar together, but it seems that, when economic freedom is more than a certain amount its positive effect on inflation will be slighter. These results are near to studies that argued about not robust negative of economic freedom on inflation such as Terra (1998) and Gruben \& MClead (2004).

\section{Conclusion}

The purpose of this study has been examining the effects of economic freedom on inflation.To do so, Gordon's adjusted triangular inflation function was considered as a theoretical base.Accounting method was using panel data about seventeen countries in the Middle East and North Africa between1996 to2006. According to the expectation, the most important factor in the inflation of countries is the structural inflation section. The highest coefficient in inflation function and its high $\mathrm{t}$ statistic confirm this idea. Economic freedom has a small positive effect on inflation.Classifyingcountries based on the degree of economic freedom and further calculating of each group) have shown that the small positive and significant coefficient is repeated for economic freedom's variable. The value of this coefficient in "nearly closed countries" is 0.001 less than its amount in "nearly free countries. It means that the inflation cost of economic freedom in less free countries is a little more than more free countries. In previous studies, the increasing effect of economic freedom on growth and employment was emphasized and according to the study's results based on the small effect of economic freedom on inflation, it is suggested that the policies which lead to the increase of economic freedom exist in developing plans of these countries in order to utilize their positive effects and it was observed that theoretically the inflation costs were very low. 


\section{References}

Alfaro, L. (2005). Inflation, openness and exchange-rate regimes the quest for short-term commitment. Journal of Development Economics, 77: 229-249.

Badinger, H. (2009). Globalization, the output-inflation. European Economic Review, 53: 888-907.

Banain, K., and Luksetich, W. A. (2001). Central bank independence, economic freedom and inflation rate. Economic Inquiry, 39: 149-161.

Barro, R. J. (1990). Government spending in a simple model of endogenous growth. Journal of political Economy, 98: 103-125.

Barro, R. J., and Lee, J. (2005). IMF programs: Who is chosen and what are effects? Journal of Monetary Economics, 52(7): 1245-1269.

Barlow, D. (2010). How did structural reform influence inflation in transition economics? Economic systems, 34: 198-210.

Carare, A. and Stone, M. R. (2006). Inflation, targeting regimes. European Economic Review, 50(5): 12971315.

Carlsson, F. and Lundstrom, S. ( 2002). Economic freedom, growth, decomposing the effect. Public Choice, 112: 335-344.

Daniels, J. P., and VanHoose, D. (2006). Openness, the sacrifice ratio, and inflation: Is there a puzzle? Journal of international Money and Finance, 25: 1336-1347.

De-Haan, J., and Strum, J. (2000). On the relationship between economic freedom and economic growth. European Journal of Political Economy, 16(2): 215-241.

Gwartney, J., and Lawson, R. (2003). The concept and measurement of economic freedom. European Journal of Political Economy, 19: 405-430.

Gruben, W. C., and MClead, D. (2004). The openness-inflation puzzle revisited. Applied Economic Letters, 11(8): 465-468.

Heritage Foundation. (2009). 6 December2009, Retrieved from (http://www.heritage.org/index/).

International Monetary Fund. (2009). September2009, Retrieved from (http://imf.org/).

Jin, J. C. (2006). Openness growth and inflation: Evidence from South Korea before the economic crises. Journal of Asian Economic, 17: 738-757.

Lane, P. (1997). Inflation in open economies. Journal of International Economics, 42: 327-347.

Romer, D. (1993). Openness and Inflation: Theory and Evidence. Quarterly Journal of Economics, 58: 869903.

Siklos, P. L. (2008). No signal definition of central bank independence is right for all countries. European Journal of Political Economy, 24(4): 802-816.

Stroup, M. D. (2007). Economic freedom, Democracy and the Quality of life. World Development, 35(1): 5266.

Sufian, F. and Habibullah, M. (2010). Does economic freedom foster bank's performance? (Panel evidence from Malaysia). Journal of contemporary accounting and economics, 6: 77-91.

Terra, C. (1998). Openness and Inflation: A New Assessment. Quarterly Journal of Economics, 63: 641-648.

World Bank (2008). World Development Indicators 2008 (WDI). Time series query. Periodical on disc database. 